\title{
ОСОБЕННОСТИ РАССМОТРЕНИЯ АРБИТРАЖНЫМИ СУДАМИ ДЕЛ ОБ ОТКАЗЕ ВО ВКЛЮЧЕНИИ ИНФОРМАЦИИ О ПОСТАВЩИКЕ (ПОДРЯДЧИКЕ, ИСПОЛНИТЕЛЕ) В РЕЕСТР НЕДОБРОСОВЕСТНЫХ ПОСТАВЩИКОВ
}

\section{SPECIFICS OF CONSIDERATION BY ARBITRATION COURTS OF CASES ON REFUSAL TO INCLUDE INFORMATION ABOUT A SUPPLIER (CONTRACTOR, PERFORMER) IN THE REGISTER OF UNSCRUPULOUS SUPPLIERS}

\section{A. Orlov}

Summary: The paper provides a comparative analysis of the former and current legislation on the contract system in the Russian Federation. Based on the examples of acts of arbitration courts, the main trends in law enforcement practice on the named problem are determined.

Keywords: contract system, arbitration process, register of unscrupulous suppliers.

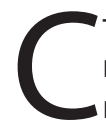
татьей 104 Федерального закона от 5 апреля 2013 года N 44-Ф3 «О контрактной системе в сфере закупок товаров, работ, услуг для обеспечения государственных и муниципальных нужд» [1] (далее - Закон № 44-Ф3) устанавливается обязанность федерального органа исполнительной власти, уполномоченного на осуществление контроля в сфере закупок (Федеральная антимонопольная служба), вести реестр недобросовестных поставщиков (подрядчиков, исполнителей). Данная мера служит для стимулирования добросовестного выполнения своих обязанностей организаций, являющихся участниками госзакупок, ведь, в случае включения организации в вышеуказанный реестр, она теряет право заключать госконтракты в течение следующих двух лет, что, безусловно негативно сказывается на прибыли.

Другой целью создания реестра является борьба с коррупцией. С помощью него предполагалось избавиться от фирм-однодневок, целью которых является снижение цены госконтракта для получения большей выгоды другой организации.

Мы не беремся судить, о том, насколько поставленные цели были выполнены, однако факт остается фактом: ни одна организация или индивидуальный предприниматель не хотят попасть в реестр недобросовестных поставщиков (подрядчиков, исполнителей) и

\author{
Орлов Антон Денисович \\ ФГБОУ ВО «Саратовская государственная \\ юридическая академия» \\ orlovad1994@mail.ru
}

Аннотация: В работе проводится сравнительный анализ бывшего и действующего законодательства о контрактной системе в Российской Федерации. На примерах актов арбитражных судов определяются основные тенденции в правоприменительной практике по названой проблеме.

Ключевые слова: контрактная система, арбитражный процесс, реестр недобросовестных поставщиков, Закон № 44-Ф3.

активно обжалуют решения антимонопольной службы о включении сведений в реестр.

Пунктом 11 статьи 104 Закона № 44-Ф3 предусмотрен судебный порядок обжалования факта включения в реестр недобросовестных поставщиков информации об участнике закупки, уклонившемся от заключения контракта, о поставщике (подрядчике, исполнителе), с которым контракт расторгнут по решению суда или в случае одностороннего отказа заказчика от исполнения контракта. На бумаге все выглядит достаточно просто: если юридическое лицо или индивидуальный предприниматель считают, что информация о них включена в реестр неправомерно - они обращаются в суд за защитой своих прав. Однако на самом деле и здесь существуют подводные камни.

Например, как следует действовать, если необходимо оспорить не факт включения недостоверных сведений в реестр, а наоборот: отказа антимонопольного органа включить участника закупки в реестр? Ведь Законом 44-Ф3 прямо не предусмотрена такая возможность.

Некую ясность внес Президиум Верховного суда РФ, выпустив обзор судебной практики применения законодательства Российской Федерации о контрактной системе в сфере закупок товаров, работ, услуг для обе- 
спечения государственных и муниципальных нужд от 28.06.2017г. [2] В пункте 42 названного обзора указано: «Необоснованный отказ антимонопольного органа во включении указанных участников закупок в реестр недобросовестных поставщиков (подрядчиков, исполнителей) прямым образом затрагивает права заказчика, поскольку участие таких лиц в последующих закупках не позволит заказчику с оптимальными издержками добиться «заданных результатов», приведет к неэффективному использованию бюджетных средств и нарушению конкуренции.

Таким образом, обеспечивая реализацию указанных принципов с учётом части 11 статьи 104 Закона о контрактной системе, заказчик как заинтересованное лицо наделен правом оспаривать в суде решение антимонопольного органа по делу об отказе во включении поставщика (подрядчика, исполнителя) в реестр недобросовестных поставщиков.»

Казалось бы, точка поставлена, вопросов быть не должно. Однако, по всей видимости, обзора судебной практики Президиума Верховного суда недостаточно для лиц, участвующих в деле, чтобы установить единый подход к применению законодательства, так как ошибки продолжали возникать. Так, например, Управление Федеральной антимонопольной службы по Ярославской области обратилось во второй арбитражный апелляционный суд, в числе прочего заявляя, что его решение о включении третьего лица, ООО «Интердорстрой», в реестр недобросовестных поставщиков не может обжаловаться в судебном порядке, так как не нарушает права и законные интересы в сфере предпринимательской и иной экономической деятельности. Конечно, суд отклонил данный довод УФАС, сославшись на обзор судебной практики Верховного суда, но факт остается фактом: сотрудники УФАС Ярославской области не учли позицию Верховного суда, что не позволительно для органа исполнительной власти [3].

Однако не только лица, участвующие в деле, допускают подобные ошибки, но и сами судьи. Так Постановлением Федерального арбитражного суда Дальневосточного округа от 23.01.2013г. № Ф03-6221/12 [4] определено, что Решение антимонопольного органа о невключении участника закупки в реестр недобросовестных поставщиков не может быть оспорено в судебном порядке, так как данный вопрос отнесен исключительно к компетенции органа исполнительной власти, осуществляющего контроль в сфере закупок. Безусловно, можно говорить о том, что в тот момент в государстве действовал Федеральный закон от 21.07.2005г. № 94-Ф3 «О размещении заказов на поставки товаров, выполнение работ, оказание услуг для государственных и муниципальных нужд» [5], однако, как мы видим, положения об оспаривании действий исполнительного органа, касающиеся включения сведений в реестр недобросовестных поставщиков прямо перекочевали из него в Закон № 44-ФЗ. Следовательно, в процессуальном законодательстве по этому вопросу ничего не изменилось.

Однако и после того, как Президиум Верховного суда РФ выпустил обзор судебной практики применения законодательства Российской Федерации о контрактной системе в сфере закупок товаров, работ, услуг для обеспечения государственных и муниципальных нужд от 28.06.2017г. случаи ошибок судей не исчезли. Так, Пятый арбитражный апелляционный суд отменил решение арбитражного суда Приморского края от 01.06.2017г., в котором последний абсолютно верно установил законность требований истца о включении сведений об участнике закупки в реестр недобросовестных поставщиков [6].

Кроме того, подобный подход наблюдается и в постановлении Девятого арбитражного апелляционного суда от 14 августа 2017 г. N 09АП-30616/2017 по делу N А40-20609/17 [7]. В нем суд посчитал, что исчерпывающий перечень обстоятельств, служащих основанием для включения сведений о поставщиках в реестр, содержится в Законе № 44-Ф3 и он не может быть расширен.

Данные факты могут свидетельствовать об отсутствии должного внимания к деятельности Верховного суда РФ по обеспечению единства судебной практики, что задекларировано как одно из полномочий Президиума.

Учитывая, что правовая система Российской Федерации не является прецедентной, обзор судебной практики Президиума Верховного суда, безусловно, не является нормативно-правовым актом. Несомненно, решение обозначенной нами проблемы должно быть найдено. Это способствовало бы становлению единой практики рассмотрения судами подобных дел и, в итоге, к снижению нагрузки на суды высших инстанций.

Для выполнения этой задачи считаем необходимым внести соответствующие поправки в Федеральный закон от 5 апреля 2013 года N 44-Ф3 «О контрактной системе в сфере закупок товаров, работ, услуг для обеспечения государственных и муниципальных нужд». А именно, изложить часть 11 статьи 104 в следующий редакции: «Включение в реестр недобросовестных поставщиков информации об участнике закупки, уклонившемся от заключения контракта, о поставщике (подрядчике, исполнителе), с которым контракт расторгнут по решению суда или в случае одностороннего отказа заказчика от исполнения контракта а также в случае неправомерного отказа федерального органа исполнительной власти уполномоченного на осуществление контроля в сфере закупок, содержащаяся в реестре недобросовестных поставщиков информация, неисполнение действий, предусмотренных частью 9 настоящей статьи, неразмещение такой информации могут быть обжалованы заинтересованным лицом в судебном порядке». 


\section{ЛИТЕРАТУРА}

1. Федеральный закон от 5 апреля 2013 г. N 44-Ф3 (в ред. от 01.09.2020 г.) «0 контрактной системе в сфере закупок товаров, работ, услуг для обеспечения государственных и муниципальных нужд» // Российская газета № 80. 2013. 12 апреля

2. Обзор судебной практики применения законодательства Российской Федерации о контрактной системе в сфере закупок товаров, работ, услуг для обеспечения государственных и муниципальных нужд (утв. Президиумом Верховного Суда РФ 28 июня 2017 г.) // Бюллетень Верховного Суда Российской Федерации № 12. 2017. Декабрь

3. Постановление Второго арбитражного апелляционного суда от 16 января 2015 г. N 02АП-9692/14 // Дело № А82-3896/2014

4. Постановление Федерального арбитражного суда Дальневосточного округа от 23.01.2013г. № Ф03-6221/12 // Дело №A 04-4406/2012

5. Федеральный закон от 21 июля 2005 г. N 94-Ф3 «0 размещении заказов на поставки товаров, выполнение работ, оказание услуг для государственных и муниципальных нужд» // Российская газета № 163. 2005. 28 июля

6. Постановление Пятого арбитражного апелляционного суда от 15.08.2017 г. № 05АП-4993/2017 // Дело № А51-32224/2016

7. Постановление Девятого арбитражного апелляционного суда от 14.08.2017 г. N 09АП-30616/2017 // Дело N A40-20609/17

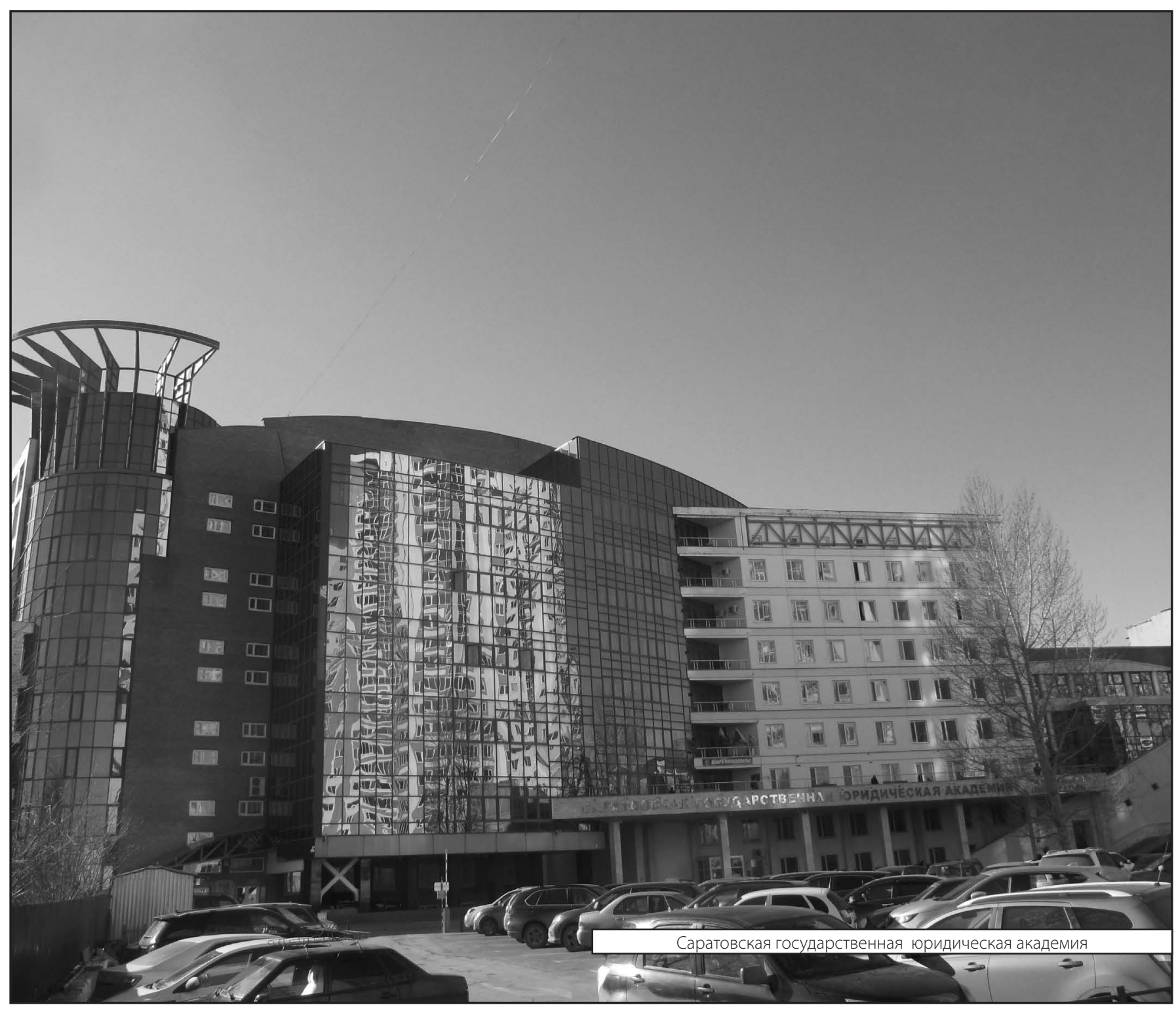

